\title{
Az űrképességek hozzájárulása Magyarország Nemzeti Biztonsági Stratégiájában foglalt feladatok megvalósításához
}

\section{How Implementing Space Capabilities can Realize the Directives of Hungary's National Security Strategy}

\author{
DanYi I.; Hamar D.; Kelemen Zs.; KöVesi Cs.; MÉSZÁros D. E.; NAGY G.; PARócZAi S.; \\ PuSZTA L.; Singlár G.; TUlOK A. ${ }^{12}$
}

Absztrakt: Magyarország Kormánya kiadta Magyarország Nemzeti Biztonsági Stratégiájáról szóló 1163/2020. (IV. 21.) Korm. határozatát, amelyben átfogó képet kapunk Magyarország jelenlegi biztonsági helyzetéről és a nemzet által elérni kívánt célokról, irányelvekrôl, valamint az azok megvalósításához szükséges eszközökröl, feladatokról. Számos, a Nemzeti Biztonsági Stratégiában foglalt célkitüzés megvalósítását képes elösegíteni egy magyar müholdrendszeren alapuló ürképesség kialakítása. Jelen tanulmányban ezt az állítást kívánjuk bizonyítani, továbbá egy átfogó kép bemutatására törekszünk egy lehetséges magyar ürképesség megvalósításának előnyeiről, igényjogosultságáról, tulajdonságairól és a megvalósításához szükséges általános feladatokról.

Abstract: The Hungarian Government has released its decree on Hungary's National Security Strategy, which provides a comprehensive picture of Hungary's present state of security, sets out the country's goals and directives to be achieved as well as the necessary government tools and tasks. Significant contributions can be made to the implementation of many of these directives by national space capabilities based on a Hungarian satellite system. In this study we intend to show the validity of this statement by presenting an overview of the legitimacy, features and possible benefits of national space-based capabilities as well as the necessary tasks involved in their implementation.

Kulcsszavak: Nemzeti Biztonsági Stratégia, üripar, űrképesség, űrtevékenység, Magyarország, EU, NATO

Keywords: National Strategy of Security, space industry, space capabilities, space activities, Hungary, EU, NATO

\footnotetext{
1 Magyar Honvédség által szervezett „Üreszközök üzemeltetése tanfolyam” hallgatói

${ }^{2}$ MTMT azonosítók: Danyi István - 10074890; Hamar Dénes - 10074220; Kelemen Zsolt - 10074620; Kövesi Csaba - 10074219; Mészáros Dalma Edina - 10074445; Nagy Gábor - 10074615; Paróczai Sándor - 10074315; Puszta Lóránt - 10074287; Singlár Gergely - 10074217; Tulok András - 10074614
} 


\section{Bevezetés}

2020-at írunk. Abba a korba érkeztünk - illetve már benne élünk - ahol a fejlődés mértékének olyan ugrásszerű növekedése várható, amelynek figyelmen kívül hagyása komoly következményeket sejtet. Tekintettel a technológia jelenlegi fejlettségi szintjére és annak fejlődésére vonatkozó töretlen igényre, elengedhetetlen a technológia alkalmazási területeinek alapvető vizsgálata ahhoz, hogy akár egy vállalkozás, akár egy nemzet, vagy bármely nemzetközi szövetség jelentős szereplője legyen a saját mércéjével mért közösségének. Ez azt jelenti, hogy amíg egy technológiai befolyásra törekvő cég anyagi szempontok szerint, addig egy nemzet szuverenitási szempontok alapján, egy politikai/gazdasági nemzetközi szervezet pedig globális vezető szerepkörének kialakításához szükséges kritériumai mentén határozza meg a célkitűzések megvalósításának eszközeit, és azok minőségét.

A Nemzeti Biztonsági Stratégiában (továbbiakban: Stratégia) foglalt célkitűzésekkel és feladatokkal összhangban egy olyan magyar űrképesség ${ }^{3}$ kifejlesztése indokolt, amely elősegíti Magyarország szuverenitásának biztosítását, teljes mértékben XXI. századi, a világ élvonalbeli technológiáit - ráadásul jelentős magyar ipari hozzájárulással - felvonultató rendszer, és amely akár az Észak-atlanti Szerződés Szervezetén (továbbiakban: NATO) belül, akár világviszonylatban is rendkívüli súlyt ad hazánknak. ${ }^{4}$

Tekintettel arra, hogy jelen publikáció egy átfogó magyar űrképesség és műholdrendszer kialakításának még csupán a tervezési-szervezési fázisában íródik, ezen oldalakon keresztül nem csupán a Stratégiában megfogalmazottak egy-egy műholdképességhez történő „párosítását” tartjuk szükségesnek. Annak érdekében, hogy egy teljesebb képet nyújtsunk a Stratégiában foglalt feladatok megvalósításához segítséget nyújtó űrképességről, törekedtünk azt több szempont vizsgálatán és ismertetésén keresztül bemutatni.

Az I. fejezetben általánosan ismertetjük az ürrendszerek által nyújtott fóbb szolgáltatási területeket. Külön hangsúlyt fektettünk az előnyök és más jelentős szempontok bemutatására.

Fontosnak tartjuk egy már működő űrképességre vonatkozó jellemzők bemutatását, amely mintegy keretrendszerbe foglalja magát az űrtevékenységet. Mindez a II. fejezetben az Amerikai Egyesült Államok által kiadott, űrképességekre vonatkozó stratégiai szintű doktrínában ${ }^{5}$ foglaltakat alapul véve kerül leírásra, a nemzeti biztonsági tényezők szem előtt tartásával.

A III. fejezetben a Stratégiában foglalt, az űrtevékenységgel támogatható feladatok és célok kerülnek bemutatásra, kiegészítve azzal, hogy ezek milyen képességgel és/vagy szolgáltatással érhetőek el. Kijelenthető, hogy az űrtevékenység már rövid távon is alapvetően hozzájárul a nemzetünk biztonságára vonatkozó stratégiai elképzelésekhez. Szem előtt kell tartanunk továbbá a nemzetközi szerepvállalásokból és kötelezettségekből fakadóan az Európai Unió (továbbiakban: EU) által meghatározott ürstratégiát és az abban foglalt célokat.

Figyelembe véve, hogy jelenleg még nem beszélhetünk egy egységes magyar űrképességről, kiemelt hangsúlyt fektettünk a jelenleg elérhető magyar űripari tevékenységek és képességek bemutatására. A

${ }^{3}$ Földi irányítás alatt álló, az űrben feladat végrehajtására alkalmas eszközzel való rendelkezés képessége ${ }^{4}$ STRATÉGIA, 2020: 167. pont

${ }^{5}$ SPACEPOWER, 2020 
IV. fejezetben megfogalmazott képességek kiválóan szemléltetik a magyarországi érdekeltségű, űriparban tevékenykedő intézmények és vállalkozások munkájában, valamint technológiai kompetenciájukban rejlő potenciált, amelynek kiaknázása alapvető és elkerülhetetlen a kívánt hazai űrképesség megvalósításában.

Az V. fejezetben egy specifikus projekt-menedzsment szemléletű elgondolást fogalmazunk meg a magyar űrképesség egy lehetséges módon történő kialakításához szükséges feladatok ismertetésére.

\section{1. Ûrképességekben rejlő potenciál}

A Stratégiában megfogalmazott, potenciálisan űrképességekkel megvalósítható feladatok és célkitűzések a III. fejezetben kerülnek bemutatásra, jelen fejezetben egy általános képet kívánunk adni egy műhold rendszer nyújtotta legrelevánsabb szolgáltatásokról, a bennük rejlő lehetôségekről és azok felhasználási területeiről.

\subsection{Távérzékelés}

Egyik legjelentősebb alkalmazhatósági terület a távérzékelés. Az űreszközre különböző mérési, illetve érzékelési célra specializált eszközöket, műszereket, érzékelőket telepítve, akár passzív (optikai képalkotás, vagy valamilyen sugárzás detektálás), akár aktív (visszavert elektromágneses jel érzékelés - radarozás, lézerszkennelés) megfigyelés során adatok gyűjthetők be a földfelszínről, légkörről és a világűr objektumairól. Fontos megjegyezni, hogy a begyüjtött adatok azonban csak a rendszerezést, kiértékelést, illetve feldolgozást követően nyernek értelmet.

Az űrből készült kép- és videofelvételek számos területen hasznosíthatók, ezért az egyik legalapvetőbb érzékelési módszer az optikai megfigyelés.

A mezőgazdaság számára fontos információval szolgálhatnak a kultúrnövényzet fejlődéséről, állapotáról, hasznosított és nem hasznosított földterületek határairól, méreteiről, felszíni vízforrások állapotáról.

A katasztrófavédelemben szintén nagy segítség lehet a nehezen megközelíthető helyszínek felderítése, erdőtüzek terjedésének, illetve szélviharok haladási irányának megfigyelése. Alkalmazhatók továbbá bármilyen egyéb természeti katasztrófával (pl.: árvíz, belvíz, földrengés stb.) sújtott területeken, vagy ember által előidézett veszélyhelyzet (pl.: kémia anyagok természetbe kerülése, radioaktív sugárzás környezetbe jutása stb.) esetén valós idejű állapot- és kárfelmérésére, a döntéshozatal elősegítésére. Valós idejű sugárzás detektálás által a radioaktív sugárzás mértékének növekedése esetén azonnali riasztás és változás követés válik lehetővé, mely képesség a katasztrófavédelmi szervek részére kiemelt fontossággal bír. Nagyban segítheti továbbá a geodéziai, térképészeti, erdőgazdálkodási, természetvédelmi szakterületek munkáját is egy műholdrendszer által nyújtott távérzékelési képesség.

Speciális hullámhossztartományra méretezett érzékelők segítségével további területek tevékenysége támogatható információkkal, hozzájárulva ezzel egy adott szakterület eredményességéhez, hatékonyságához. Egyik ilyen kiemelendő felhasználói szakterület a meteorológia. Űreszközre telepített meteorológiai szenzorok segítségével terület specifikus, valós idejű adatok által nagyfokú pontosság érhető el az időjárás előrejelzésében, a hőmérséklet eloszlásának feltérképezésében, hatékonyabbá 
válhat a légköri változások/anomáliák figyelése, elemzése, továbbá megfigyelhető az ózonréteg állapota és a károsanyag kibocsátása. A meteorológia fejlődése, a megbízhatóbb jelentések az ezen információkat felhasználó szakterületek hatékonyságának növekedését is jelenti, amelyre jó példa a repülésirányítás.

\subsection{Távközlés}

Kommunikációs célra fejlesztett műhold képes egy adott nemzet interkontinentális beszédcélú és szélessávú internet szolgáltatás, valamint kereskedelmi műsorszórás (műholdas televíziózás) igényét önállóan biztosítani. Ezen túlmenően lehetőség nyílik olyan válsághelyzetek kezelésének kommunikációs támogatására is, amelyek megkívánják a gyors beavatkozást, ezáltal szükségessé válik a magas rendelkezésre állást és a nagy adatátviteli sebességet biztosító múholdas kommunikációs rendszer alkalmazása.

A műholdas kommunikációt és műsorszórást megvalósító rendszer kialakítása számtalan előnnyel bír a hagyományos földi rendszerekhez képest. A földfelszín közelében megvalósítható nagytávolságú kommunikációs kapcsolatok közül egyedül az optikai fényvezetők rendelkeznek magasabb adatátviteli sebességgel azonban az ilyen hálózatok tervezési és kiépítési költsége, a megvalósításhoz szükséges engedélyek megszerzése, valamint hosszú távú fenntartása magasabb költséggel jár. A nagy távolságú (40-70 km) mikrohullámú pont-pont (állandó telepítésű) összeköttetések alkalmazhatóságát a domborzat erősen befolyásolja, mivel a stabil kapcsolathoz közvetlen optikai rálátás szükséges. Ezen túlmenően a nagy távolságok miatt a mikrohullámú pont-pont összeköttetések adatátviteli sebessége műszaki (használható frekvencia sáv) és mechanikai (antenna méret növekedés) okok miatt csökken, ezért a műholdas rendszer által biztosított átviteli kapacitás vetekszik a nagy távolságú mikrohullámú összeköttetések sebességével. Léteznek olyan mikrohullámú pont-pont berendezések, amelyek elérhető adatátviteli sebessége többszörösen meghaladja a műholdas eszközök által biztosítottat, de ezek az összeköttetések csak néhány kilométeres távolságot képesek áthidalni, ami nagyban korlátozza az alkalmazhatóságukat.

A fenti rendszerek és azok sajátossága miatt egyértelműen belátható, hogy alkalmazásuk csak stacioner körülmények között válik lehetségessé. Amennyiben a gyors és rugalmas helyváltoztatás, az elérhető magas adatátviteli sebesség és a magas rendelkezésre állás biztosítása egyidejűleg szükséges, akkor ez műholdas kommunikáció alkalmazásával érhető el. Előnye továbbá, hogy a műholdas rendszer képes egy időben több földi végpontot is kiszolgálni az elérhető adatátviteli kapacitás dinamikus vagy akár dedikált módon történő kezelésével, további rugalmasságot biztosítva ezzel az igénybe vevők számára.

Lehetőség nyílik állandó vagy ideiglenes jelleggel biztonságos, minősített adattovábbításra alkalmas kommunikációs csatornák kiépítésére is, melyek felhasználhatók akár kormányzati-, vagy nemzetvédelmi célú adatkapcsolat kialakítására.

\subsection{Kutatás-fejlesztés}

Általánosan elmondható, hogy az űrképesség kialakítása, valamint az űripar fellendítése a gazdaság több ágazatát is arra ösztönzi majd, hogy kutatásokat-fejlesztéseket végezzenek annak érdekében, hogy kiszolgálhassák az űrszektor megrendeléseit, illetve a kutatások eredményeinek tükrében egyre újabb, hatékonyabb megoldásokra törekedjenek. 


\subsection{Nemzeti biztonság}

A légtér, a szárazföld és a tengerek mellett, a kibertér után a világürt is múveleti hadszíntérré minősítette a NATO, űrképességek nélkül már-már elképzelhetetlen nemzeti szuverenitás kiépítése, megőrzése.

Az ártó szándékra való felkészülés felfedése, azonnali észlelése, de akár egy alkalmas űreszköz pályára állítása vagy mozgatása is képes visszatartani a konfliktustól a másik felet. Ez alapján kijelenthető, hogy az állam biztonságát az ûrképességek egyértelműen növelik.

\section{Védelmi célú űrképességekről általánosan6}

Az űrben végrehajtott műveletek mára már túlmutatnak egy eszköz feljuttatásán és annak pályára állításán, vagy az emberes repülésen. A nemzetközi szabályozás meghatározza a világűr kizárólag békés célú felhasználását, ugyanakkor a NATO aktuális állásfoglalása e tekintetben a védelmi célú alkalmazásnak is teret enged ${ }^{7}$.

A bolygónk körül zajló űrtevékenységeknek számos ország a résztvevője, ezen nemzetek közül alig néhány rendelkezik olyan infrastruktúrával, mellyel eszközt vagy akár embert is fel tud juttatni Föld körüli pályára. A Föld körül zajló műveletek érdemi szereplői egyértelműen a különböző magasságokon üzemelő műholdak és az azok által képzett rendszerek.

A műholdak manapság meghatározó szerepet töltenek be a kommunikáció-, időjárás előrejelzés-, a helymeghatározás- és a navigáció biztosításában. Ezek javarészt békés célú felhasználások, de a modern kor követelményeinek megfelelően katonai felderítési és hírszerzési célokra is alkalmazhatók. Egyes országok különösen nagy hangsúlyt fektetnek a ballisztikus rakéták korai észlelésére és egyéb eszközök, objektumok nyomon követésére.

Az űrben zajló tevékenységek nevükből fakadóan a földi korlátoktól kevésbé függenek, flexibilisek, így igen hatékonyan járulnak hozzá egy ország állami tevékenységének támogatásához. Fontos megemlíteni, hogy ezek a műveletek nem feltétlen maradnak teljes titokban és más nemzetek is tudomást szerezhetnek ezekről, hiszen hasonló eszközöket alkalmaznak saját biztonságuk érdekében. Ám maga a tudat, hogy bizonyos képességekkel az ellenérdekelt fél is rendelkezik, bölcs és megfontolt cselekvésre ösztönözheti a döntéshozókat.

A fenti védelmi célú képességek meglehetősen sokszínűek, változatosak. Az első és talán legfontosabb az, hogy maguk a képességeket biztosító eszközök megfelelő védelemmel legyenek ellátva. Képesek legyenek manőverezni, kitérni egy adott támadás elől, fenntartva a rájuk bízott feladat folyamatos végrehajtásának képességét.

A modern műholdak védelmi rendszereinek vonatkozásában az elektromágneses- és kiber támadások, továbbá az azok elleni védelem játszik kulcsszerepet. Ehhez az elektromágneses spektrum-, a frekvencia

\footnotetext{
${ }^{6}$ SPACEPOWER, 2020

${ }^{7}$ NATO'S APPROACH TO SPACE
} 
manőverek ismerete, valamint a nem kinetikus támadások felismerése elengedhetetlen. Ezáltal könnyen kialakítható a műveleti fölény akár egy ismeretlen féllel szemben is.

$\mathrm{Az}$ alkalmazásuk során, a műveletekben résztvevő eszközök helyzetének és képességének számontartása az Ûrben is elengedhetetlen tudás, a misszió teljesítésének biztosítéka. A változó környezeti fenyegetések számontartásával növelhető a saját eszközök védelme.

Szintén fontos megemlíteni, hogy az ưrben lévő képességek maximális kihasználhatósága érdekében elengedhetetlen a földi támogatás. Ezen eszközöknek és rendszereknek mindig rendelkezésre kell állniuk. Kiemelkedő szerepet kap az üzemeltetés stabilitása, annak logisztikai támogatása és a folyamatos működéshez szükséges források biztosítása.

A katonai értékelés és elemzés fontos alappillére a hatásalapú múveletek lebonyolításának. Mindazonáltal elengedhetetlen, hogy az űreszköz rendelkezzen az Űr és a földi szegmens védelméhez szükséges megfigyelési és felderítési képességekkel.

Az eszközök önálló tevékenységre csak bizonyos szintig alkalmasak, nem szabad megfeledkezni az emberi tényezőről sem. Ezen eszközök által biztosított képességek teljes mértékű kiaknázásához megfelelő szakmai tudással rendelkező, felkészült földi irányító személyzet szükséges. A szakmai tudás mellett törekedni kell nemzetközi kapcsolatok kialakítására és együtt kell működni más hasonló célokkal rendelkező partner szervezetekkel.

A fentiek ismeretében kijelenthető, hogy az űrképesség egy több szegmensből álló, összetett rendszer, mely nem csak egy adott űreszköz pályára állításáról és annak üzemeltetéséről szól. Az űrképesség a mai modern világban döntően befolyásolja egy nemzet biztonságát, gazdaságát és nagyban hozzájárulhat egy ország döntés hozatali folyamatainak felgyorsításához.

Különösen igaz ez az előttünk álló időszakra nézve, hiszen a világ biztonsági környezete alapvető változásokon megy keresztül. Új gondolkodásmód szükséges az új kihívások által támasztott problémák megoldására. A legfontosabb kihívások közé sorolható az átalakuló világrend, a klíma- és demográfiai változások, valamint a természetes erőforrások felhasználása és nem utolsó sorban a technikai fejlődés társadalomra gyakorolt hatása. ${ }^{8}$

„Magyarország Nemzeti Biztonsági Stratégiájának célja hazánk jelenlegi biztonsági szintjének megőrzése és erősítése, ennek nyomán pedig az ország további fejlődésének szavatolása egy változékony világban". ${ }^{9}$ A további fejlődéshez és a biztonság fokozásához elengedhetetlenül fontos a jelenlegi védelmi rendszerek fejlesztése és újabbak létrehozása (amelyre a III. fejezet részletesebben kitér). Kiemelt területek az információs műveletek és a kiberhadviselés elleni védekezés, valamint az infokommunikációs rendszerek védelmének erősítése.

\footnotetext{
${ }^{8}$ STRATÉGIA, 2020: 1 . pont
}

${ }^{9}$ STRATÉGIA, 2020: 3. pont 


\section{3. Ûrképességgel elérhető, a stratégiában foglalt feladatok és célok}

A nemzeti űrképesség létjogosultságát és szükségességét mi sem bizonyítja jobban, hogy a Stratégia egyértelműen kitér az űrszektorban való megjelenés fontosságára. A Stratégiában megfogalmazott feladatok, célkitűzések megvalósításának célja hazánk jelenlegi biztonsági szintjének megőrzése és erősítése. Az űrképességekben rejlő potenciálok, lehetőségek nagyban képesek hozzájárulni ezen kihívásokra keresendő válaszok megtalálására.

A Stratégiában megfogalmazott 179 pont döntő többségéhez társítható olyan űrképesség, amelyek segítségével a feladatok végrehajtása támogatható.

Az a törekvés mely szerint Magyarország 2030-ra Európa öt, illetve a világ tíz legbiztonságosabb ország egyike legyen, több területen való stratégiai fejlesztést, képesség fokozást követel meg, melyekhez az űrtevékenység nagyban hozzá tud járulni.

\subsection{Nemzeti biztonság szintjének megőrzése, fejlesztése}

A nemzeti űrtevékenység hazánk jelenlegi biztonsági szintjének megőrzésében és erősítésében új eszközként szolgálhat. ${ }^{10}$ Magyarország nemzeti űrképesség hiányában jelenleg bérelt szolgáltatások felhasználásával, külföldi szolgáltatók bevonásával vesz igénybe műholdas szolgáltatásokat. Ezzel szemben egy szuverén müholdflotta magasabb fokú biztonságot képes szavatolni. A saját eszközpark és üzemeltetési képesség nagymértékben erősítené a nemzetgazdaságot, különös tekintettel a védelmi ipart, ami kulcsfontosságú tényező az elvárt biztonsági szint eléréséhez ${ }^{11}$. Mérséklődne a műholdas képesség rendszereihez történő jogtalan hozzáférés lehetősége, az információk védelme ezáltal nagyban elősegíti az innovatív védelmi rendszer kialakítására irányuló törekvések elérését. ${ }^{12}$. Az üriparral elérhető képességekkel lehetőség nyílik a védelmi ipar bizonyos szegmenseinek támogatására, biztosítva a nemzeti biztonság szintjének erôsítését. Az űrképesség kialakulásával egyidejűleg a védelmi iparban is megjelenhet olyan új potenciál, melyre korábban az űrképesség hiányában nem nyílt lehetőség. Nemzeti ûripar létrejöttével lehetőségünk nyílna a nemzetközi védelmi ipar ${ }^{13}$ értékláncokba történő becsatlakozásra is.

A hazai védelmi ipar ${ }^{14}$ fejlesztéséhez alapvető kritérium egy korszerű haderő felépítése, haderőfejlesztési célok megvalósítása a Magyar Honvédség keretein belül ${ }^{15}$. A haderőfejlesztés fontos elvárása, hogy képes legyen beavatkozni a hazánk szempontjából releváns összes műveleti térben történő eseményekbe. Jelenleg ez három területet foglal magába: szárazföld, légtér és kibertér. Ha ezek a műveleti területek kiegészülnének a világűrrel, az jelentős nemzeti és nemzetközi presztízsnövekedést

\footnotetext{
${ }^{10}$ STRATÉGIA, 2020: 3., 126. pont

${ }^{11}$ STRATÉGIA, 2020: 2. pont

${ }^{12}$ STRATÉGIA, 2020: 128. pont

${ }^{13}$ STRATÉGIA, 2020: 29. pont

${ }^{14}$ STRATÉGIA, 2020: 5., 28. pont

${ }^{15}$ STRATÉGIA, 2020: 134., 135., 136. pont
} 
eredményezne. Nemzetközi együttműködés keretein belül lehetőség nyílna továbbá haditengerészeti műveletekben távközlési vagy távérzékelési szolgáltatásokkal történő támogatásra. A védelmi célú űrtevékenység, az általa nyújtott szolgáltatásaival nagymértékű képességnövekedést jelentene a honvédelem vonatkozásában. Ez lehetőséget biztosíthat a társszervezetek - a rendvédelem, katasztrófavédelem, terror-elhárítás - tevékenységének támogatására is. ${ }^{16}$

Tekintettel arra, hogy a Magyar Honvédség hazánk szuverenitása és területi integritása szavatolásának alapvető intézménye ${ }^{17}$, ezért a más államoktól való függés minimalizálása nemzetünk alapvető törekvése ${ }^{18}$. A nemzeti űrképesség elérése a cselekvési szabadság megszerzése, szuverén műhold infrastruktúra üzemeltetése, másik féltől való függőség megszüntetése a nemzet biztonságának jelentős javulását eredményezné.

A távérzékelésre alkalmas műholdak segítségével támogatható a fizikai határaink ellenőrzése, az ország szuverenitásának és területi épségének védelme. Ez nem csak az ország biztonságát növelné, hanem az európai kontinens biztonságának és stabilitásának megtartásához, felerősítéséhez is hozzájárulna. ${ }^{19}$

A titkos információgyűjtés koncentrált eszközrendszere a távérzékelés képességével támogatható, ezzel elősegítve a nemzetbiztonsági szolgálatok hírszerző és elhárító tevékenységének hatékonyságát. ${ }^{20}$.

\subsection{Nemzetközi szerepvállalás, kötelezettségek és együttműködés}

Magyarország biztonsági helyzetét nagyban befolyásolja a nemzetközi szervezetekkel ${ }^{21}$, más országokkal történő együttműködés. E tekintetben a NATO és EU tagságunk kiemelt fontosságú, amely a biztonsági környezetünk alapjait határozza meg. Nemzetközi kötelezettségeink teljesítéséhez kiemelve a NATO 5. cikkelye által szavatolt kollektív védelmi törekvéseket - ürképesség kialakításával nagyobb mértékben tudunk hozzájárulni.

A biztonsági környezetben lévő katonai szerepvállalás megnövekedése világviszonylatban is érzékelhető. ${ }^{22} \mathrm{Az}$ európai országok által folytatott képességnövelési erőfeszítések meghatározóak a kontinens hosszú távú biztonságának megőrzéséhez. Kulcsfontosságú tényező a biztonsági helyzetünkre vonatkozóan a más országokkal való együttműködés magas szintjének fenntartása, közös biztonság- és védelempolitikai együttműködés ${ }^{23}$, melyeket egy saját nemzet által rendelkezésre álló űrképességek felajánlása más nemzetek részére nagyban elősegíti és támogatja.

Katonai nemzetvédelmi képesség lehet egy automatizált erőkövetési rendszer, mely illeszthető a szövetséges erők ilyen célú rendszeréhez, továbbá a nemzetközi szerepvállalás révén kiküldött személyi

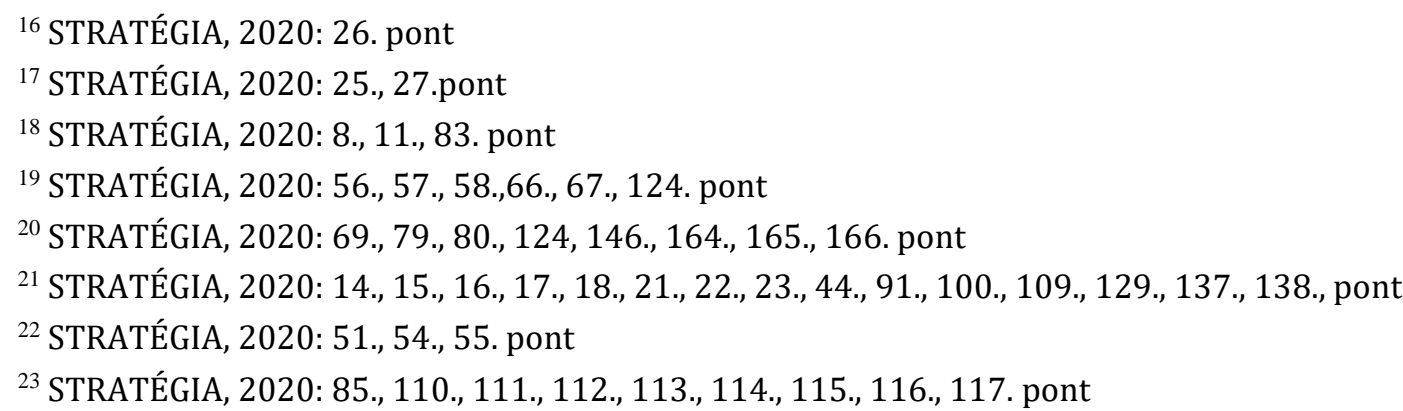


állomány és az anyaország közti gyorsan telepíthető, biztonságos, zártcélú kommunikáció is, mely megvalósítható üreszköz(ök) használatával.

Tekintettel hazánk nemzetközi szerepvállalásának és kötelezettségeinek kritikus fontosságára, figyelemmel kell lennünk az EU által megfogalmazott űrstratégiai célokra is ${ }^{2425}$ :

- A világűr nyújtotta előnyök maximalizálása a társadalom és az EU gazdasága számára

- Az európai ürszektor globális versenyképességének növelése

- Európa függetlenségének további erősítése az űrhöz való hozzáférésben

- Európa szerepének megerősítése az űrszektorban

- Ezen stratégiai célok támogatására egy önálló nemzeti űrképesség kialakítása révén tudunk szert tenni.

\subsection{Szakmai képességek fejlesztése}

Minden új rendszer, stratégia egyik alappillére a jól felkészített szakértői állomány. Az ürszegmens bevonása az oktatási és képzési rendszerbe ${ }^{26}$ olyan speciális természettudományos és műszaki ismeretek oktatását eredményezi, ami a nemzetközi tudományos és technológiai versenyben elfoglalt pozíciónkra pozitív hatással lehet, amely biztonságpolitikai jelentőséggel is bír. Ez a folyamat eredményezi a kutatás fejlesztését, innováció támogatását és megjelennek a képességfejlesztési kezdeményezések ${ }^{27}$, amik szintén az iparág fejlődését vonják maguk után. A nemzeti ûripar magába foglalja az űrtevékenységgel összefüggő projektek, technológiák megtervezésére, megvalósítására szakosodott vállalatok, vállalkozások megjelenését a hazai piacon, amelyek hozzájárulnak az ország gazdasági növekedéséhez ${ }^{28}$, valamint nemzetközi szinten is versenyképessé válhatnak, ezáltal erősítve az ország hírnevét ezen a területen.

\subsection{Természeti erőforrások védelme}

Természeti erőforrásaink, különösen a vízbázisok és a termőföld fokozott védelme ${ }^{29}$ elengedhetetlen egy stabil gazdaság, környezeti biztonság megteremtéséhez. Itt szintén nagy jelentősége van a távérzékelésnek. Ez által figyelhető, rögzíthető, előre jelezhető az ezeken a területeken bekövetkező változások. Az éghajlatváltozás hatásai, a globális felmelegedés ${ }^{30}$ komplex kihívásokat generálnak ezen a téren. Egy múhold meteorológiai szenzorokkal, műszerekkel történő felszerelése nagyban

\footnotetext{
${ }^{24}$ SPACE STRATEGY FOR EUROPE

${ }^{25}$ Az új „SPACE STRATEGY FOR EUROPE” 2020. 09. 28. és 2020. 10. 05 között kerül megfogalmazásra a Brüsszelben megrendezésre kerülő „European Space Expo” keretein belül

${ }^{26}$ STRATÉGIA, 2020: 42. pont

${ }^{27}$ STRATÉGIA, 2020: 105., 106., 107., 121., 122., 128., 141. pont

${ }^{28}$ STRATÉGIA, 2020: 37. pont

${ }^{29}$ STRATÉGIA, 2020: 123., 171. pont

${ }^{30}$ STRATÉGIA, 2020: 49., 124. pont
} 
hozzájárulhat a szélsőséges időjárási viszontagságok előrejelzéséhez, amellyel a nemzeti élelmiszerellátottság biztonsága fokazható ${ }^{31}$.

\section{5. Űrtechnológia, űrszektorban való megjelenés}

A Stratégia 73. pontja az alábbi módon fogalmazza meg az űrszektor jelentőségét egy biztonságos Magyarország megteremtése szempontjából: „Az űrtechnológia területén bekövetkezett rendkívül gyors fejlődés következtében a terület hatalmas technológiai minőség ugrás elé néz. Az élboly és a lemaradók között a technológiai rés folyamatosan nő. Az űrtechnológia, mint a piramis csúcsán elhelyezkedő ágazatok egyike, ami meghatározó jelentőségű lesz egy-egy ország fejlettségét, gazdasági, társadalmi erejét és viszonyait, politikai érdekérvényesítő képességét tekintve." Jól érzékelhető tehát az innováción alapuló űrszektorban való megjelenés fontossága ${ }^{32}$. A világűr ellenőrzéséért fokozódó küzdelembe ${ }^{33}$ időben beszálló nemzetek nemzeti biztonsági, gazdasági javakat szolgáló előnyökhöz való jutása megkérdőjelezhetetlen.

\section{Magyar űripari képességek ${ }^{34}$}

A Stratégia irányelveivel, meghatározott feladataival összhangban, a jövőbeli hazai űrképesség kialakítása, realizálása érdekében vizsgálni érdemes az űreszközök gyártástechnológiájának képességével rendelkező és az űrszegmensben szolgáltatást nyújtó, kutatást végző magyar cégeket, intézményeket.

A magyar űripari vállalkozások külföldi és hazai megrendelésekből eredően számottevő tapasztalattal rendelkeznek az egyes űreszköz-fedélzeti rendszerelemek kivitelezésében, előállításában. A Magyar Ûripari Klaszter (továbbiakban: HUNSPACE) egy olyan szervezet, amely a hazai űripar aktív szereplőit fogja össze. A HUNSPACE szakszervezeti jellegű érdekképviseletet nyújt azon magyar cégek számára, akik elfogadják a klaszter tagság feltételeit és egy megállapodásban kifejezik az együttműködési szándékukat a magyar űrtevékenység, nevezetesen az ipar, a kutatás és az oktatás segítése érdekében. A klaszter tagság előnye, hogy folyamatos tájékoztatásban részesülnek az együttműködő cégek egymás munkájáról. A HUNSPACE transzparens képet nyújt a hazai űripar potenciális szereplőinek gyártástechnológiai képességeiről és erőforrásairól.

A hazai űrtechnológiai kutatóhelyek tekintetében a Magyar Repülő és Ûrtechnológiai Platform (HATP) kezdeményezett összefogást. A platform tagjai között találhatunk repülési és űripari cégeket, melyek többsége laboratóriumi környezettel is rendelkezik az egyes űrtechnológiai eszközök, alkatrészek

31 STRATÉGIA, 2020: 38. pont

32 STRATÉGIA, 2020: 167. pont

33 STRATÉGIA, 2020: 48. pont

34Források:

ÜRKÖRKÉP, 2019

HUNSPACE

C3S 
gyártási- és üzemi-tesztjeinek végrehajtásához, vizsgálatához. Az egyetemi és akadémiai kutatóhelyekkel karöltve nem csak hazai, hanem külföldi szervezetekkel is törekednek együttmúködés kialakítására olyan kutatási és fejlesztési területekhez, mint például a műholdas berendezések újszerű megoldásainak keresése vagy a műholdas földi infrastruktúra korszerű eszközökkel történő optimalizálása.

Az általános terminológia lehetőséget ad az üriparban működő cégek megkülönböztetésére. Az „Upstream” jellegű vállalatok az űreszközök felbocsátását vagy annak specifikus fedélzeti elemét, építését tűzik ki célul. A „Downstream” jellegű alkalmazásokkal bíró cégek a világűrből származó adatokon alapuló szolgáltatásokat biztosítják. A kutatási „Research” tevékenységgel bíró szervezetek pedig az űripar harmadik ágát képviselik. A magyar űrszektor mindhárom területen rendelkezik már működő piaci és nonprofit szervezettel. Az alábbiakban - a teljesség igénye nélkül - a legrelevánsabb magyar űripari képességek kerülnek ismertetésre (egy adott képességhez tartozóan a különböző kompetenciával rendelkező hazai űrklaszter szervezetek lábjegyzetben való feltüntetésével).

\section{1. Űreszköz fedélzeti adatrendszer kialakítás ${ }^{35}$}

Hazánkban fellelhető olyan cég, amely tudományos kutatások kísérleteihez fedélzeti műszerek támogatására fejleszt nagy megbízhatóságú fedélzeti vezérlő és adatgyűjtő rendszereket, valamint azok földi ellenőrző berendezéseit.

Rendelkezésre áll a képesség komplett szoftveres és hardveres elektronikai rendszermegoldások kivitelezéséhez. A fedélzeti adatrendszereket különálló technológiai kompetenciának tekinti az ESA, amelyet három részre osztanak: 1.) Hasznos adatfeldolgozás; 2.) Fedélzeti adatkezelés; 3.) Mikroelektronika digitális és analóg alkalmazásokhoz. A hazai felsőoktatásban kutatási oldalról rendelkeznek tapasztalattal a fedélzeti adatrendszerek kialakításában, tervezni képesek a fedélzeti kísérletekhez és alkalmazásokhoz - gyakorlati múhold üzemeltetési tapasztalat alapján is - az elektronikai rendszerek világűrben történő alkalmazásba vételét.

\section{2. Û́reszköz- / földi- rendszerszoftver allokálás ${ }^{36}$}

Rendszerszoftver allokálás képességben jártas cégeket is találhatunk hazánkban, míg a kutatási képesség szintén felsőoktatási intézmény sajátja. Ez a technológiai kompetencia négy részre osztható: 1.) Fejlett szoftvertechnológiák; 2.) Világűrszegmensben alkalmazott szoftverek; 3.) Földi szegmensű szoftverek; 4.) Földi adatfeldolgozás szoftverei.

\footnotetext{
${ }^{35}$ technológia, kutatás: BL-Electronics Kft., Budapesti Műszaki Egyetem - Szélessávú Hírközlési és Villamosságtan Tanszék, C3S Elektronikai Fejlesztő Kft., Csillagászati és Földtudományi Kutatóközpont, Konkoly Thege Miklós Csillagászati Intézet, Energiatudományi Kutatóközpont, Eötvös Lóránt Tudományegyetem, SGF Technológia Fejlesztő Kft., Wigner Fizikai Kutatóközpont Részecske és Magfizikai Intézet

${ }^{36}$ technológia, kutatás: BL-Electronics Kft., Budapesti Műszaki Egyetem, Budapesti Műszaki Egyetem Szélessávú Hírközlési és Villamosságtan Tanszék, C3S Elektronikai Fejlesztő Kft., SGF Technológia Fejlesztő Kft, Wigner Fizikai Kutatóközpont Részecske és Magfizikai Intézet
} 
Mára már hazai környezetben, az űreszköz felbocsátását megelőző szimulációs szoftver is a rendelkezésre áll. Egy hazai intézet nagy megbízhatóságú fedélzeti műszerekhez, rendszerekhez, illetve azok földi ellenőrző berendezéseihez kapcsolódó hardver- és szoftver fejlesztéssel is foglalkozik.

\subsection{Sugárzásálló digitális űrtechnológia ${ }^{37}$}

A kompakt, nagy megbízhatóságú, kis fogyasztású, sugárzásálló technológia fejlesztését műholdas környezetre szintén képes hazai cég kivitelezni. Sugárzásálló, digitális űrtechnológiai projektet a Nemzeti Kutatási Fejlesztési és Innovációs Hivatal is támogat. ${ }^{38}$

\subsection{Termikusan optimalizált műholdstruktúra termékcsalád fejlesztése ${ }^{39}$}

A termikusan optimalizált kis-műholdas mechanikai architektúrák kialakítását, fejlesztését hazai cég is képes kivitelezni. Olyan vállalkozással is találkozhatunk a hazai üripari klaszterben, amely laboratóriumi rezgésvizsgálati képességet biztosít - adott esetben - a fedélzeti rendszerek hőváltozási és rezgések által kiváltott deformálódási, anyag öregedési vizsgálatok érdekében. Ez lehetővé teszi a magas igényű, ISO ${ }^{40}$ minősítésű rezgéstesztek elvégzését, amelyeket az űripar követel meg. Egy másik cég szerkezeti és termikus tervezést is végez űripari projektekben, műhold-radiátorok előállítására képes, tapasztalata van a rakétakúp-gyártásban, többrétegű szigetelőpaplan, oldalfal-radiátor és külső marker megoldások fejlesztésében.

\subsection{Távérzékelés ${ }^{41}$}

Az űrfelvételek széles körű feldolgozását, tovább hasznosítását képes hazai cég képfeldolgozó rendszereken keresztül biztosítani. A képi információkra épülő értéknövelt termékek létrehozása is adott. A térinformatikai képességek nagyban hozzájárulnak a tevékenység kibővítéséhez.

Egyik példaként a mezőgazdasági alkalmazások különböző területeit lehet kiemelni. Korszerű, innovatív és nemzetközileg is új módszereket alkalmaz egy hazai cég szakembergárdája. Tevékenységüknek köszönhetően a gazdaságok, a mezőgazdasági táblák termésének mérésében és a termés előrejelzésben tudnak közreműködni. A nemzeti adminisztráció is egyik alkalmazója. Egyik hazai felsőoktatási intézményünk sajátjának mondhatja ezt a kutatási területet, mint műholdas távérzékelést - elsősorban az ipari növények termésbecslését végzik.

Egy hazai cég portfóliójába tartozik a különböző távérzékelési eljárások (légi, UAV, műhold) alkalmazási lehetőségeinek számbavétele. Ez konkrétan az adatgyűjtésben, adat-feldolgozásban, különböző

\footnotetext{
37 technológia: C3S Elektronikai Fejlesztő Kft.

${ }^{38}$ C3S, https://www.c3s.hu/hu/rdsp/

${ }^{39}$ technológia, kutatás: C3S Elektronikai Fejlesztő Kft.

${ }^{40}$ Nemzetközi Szabványügyi Szervezet

${ }^{41}$ technológia, kutatás: Airbus DS GEO Hungary Kft., Eötvös Lóránt Tudományegyetem Geofizikai és

Ûrrtudományi Tanszék - Û́rkutató Csoport, Environsense Hungary Kft., Lechner Tudásközpont Területi, Építészeti és Informatikai Nonprofit Kft., Space Apps Kft.)
} 
termékek előállításában, illetve automatizált térképi információszolgáltató rendszerek fejlesztésében és üzemeltetésében nyilvánul meg. A műholdas adatok segítségével, térképi információszolgáltatással lehetőség nyílik a döntés-előkészítés támogatására.

Szintén számolhatunk egy távérzékeléssel foglalkozó magyar céggel, akik tapasztalattal rendelkeznek olyan távérzékelési adatok feldolgozásában, amely során hatékonyan támogatta az államigazgatást (mezőgazdaság, katasztrófavédelem, természetvédelem, területi adminisztráció), az ipari és egyéb szolgáltatásokat, mint a közlekedési és járműipar, biztosítási szolgáltatások, építőipar.

Fontosnak tartjuk megemlíteni, hogy az Országos Meteorológiai Szolgálat kiterjedt felszíni és távérzékelési mérőhálózatot, valamint fejlett informatikai és telekommunikációs hálózatot működtet.

\section{6. Űreszköz energiaellátó modul (EPS) fejlesztés, tervezés, gyártás ${ }^{42}$}

Létezik olyan hazai cég, amely az EPS tervezés során thermovákuumban végez tesztet és rázási, valamint sugárzási teszteknek is aláveti az egyes energiaellátó moduljait. Említésre méltó, hogy hazai gyártástechnológiai körülményeik között a napelem elrendezési konstrukciók nagyfokú szabadságot ígérnek a megvalósítást illetően, az energiaellátásról a műholdpálya árnyékos szakaszán az újratölthető akkumulátoros megoldást is kivitelezik. Redundancia biztosíthatja az üzemszerű múködést, tartalékolást. Kutatási oldalról felsőoktatási intézmény rendelkezik képességgel az EPS modulok optimalizálását illetően. Ez a technológiai kompetencia négy részre osztható: 1.) Az energiaellátó rendszer architektúrája; 2.) Energiatermelő technológiák; 3.) Energiatárolási technológiák 4.) Áramellátás és elosztás.

\section{7. Űreszköz/jármű környezeti hatásvizsgálat ${ }^{43}$}

Ezen technológiai kapacitással rendelkező hazai szervezetek vizsgálják az űreszközök világűrben elfoglalt helyzetét, az eszközöket érő űrkörnyezeti hatásokat.

Hazai földtani intézetünk sajátja (CSFK Geodéziai és Geofizikai Intézet), hogy egyedi laboratóriumi kapacitást képvisel. Tapasztalattal rendelkezik az ürszondás detektorok tesztelésében, földi referenciamérések kivitelezésében. A nemzetközi projektekben szerzett tapasztalatuk olyan képességet tesz lehetővé, mint például az infravörös detektorok által érzékelt meteoritásványok infravörös reflexiós színképeinek elemzése. Az intézet geofizikai és geodéziai kutatásának űrkutatási vonatkozása is van. A kutatásokhoz egy magyar obszervatórium észleléseit és nemzetközi együttmúködési keretrendszerben a műholdas missziók mérési adatait használják. Az intézet fő űrszektort érintő

\footnotetext{
${ }^{42}$ technológia, kutatás: Budapesti Műszaki Egyetem, Budapesti Műszaki Egyetem - Szélessávú Hírközlési és Villamosságtan Tanszék, C3S Elektronikai Fejlesztő Kft., Wigner Fizikai Kutatóközpont Részecske és Magfizikai Intézet

${ }^{43}$ technológia, kutatás: Energiatudományi Kutatóközpont, Eötvös Lóránt Tudományegyetem
} 
területei a geomágneses- és az az űrgeodéziai ${ }^{44}$ kutatások végzése. Speciális frekvenciasávban (ELF ${ }^{45}$ frekvenciasáv - Schumann-rezonancia) képes aeronómiai ${ }^{46}$ vizsgálatokat végezni az ionoszféra és a földfelszín közötti térrészben fellépő tranziens elektromágneses jelenségek kutatásában. A geomágneses kutatások dinamó-modellezést, napszél-magnetoszféra kölcsönhatás vizsgálatokat tesznek lehetővé, magába foglalva a geomágneses indukció alkalmazását (magnetotellurika) és az indukciós kockázat elemzés képességét is.

\section{8. Űrtávközlési rádiófrekvenciás optimalizáció és rendszertervezés ${ }^{47}$}

A hazai képesség magában foglalja a telekommunikációs alrendszerek, a rádiónavigációs alrendszerek, telemetriai alrendszerek, mikro és milliméteres hullámsávú technológiák és hírközlési eszközök (TT\&C - Tracking Telemetry and Command) kivitelezését, telepítését.

Hazánkban jelen van olyan cég, amely gyártott már olyan rádióelektronikai berendezéseket, amelyek megtalálhatók a Nemzetközi Û́rállomáson és műholdkövető földi állomásokon.

A hazai képesség a műholdkövető és földi vezérlő állomások vonatkozásában biztosítja a VHF, L, S, C, X, $\mathrm{Ku}, \mathrm{K}, \mathrm{Ka}$ sávban optimalizált berendezések, frekvencia-szintézerek és mikrohullámú erősítők implementálását.

\subsection{Repülési dinamika és GNSS ${ }^{48}$}

Hazai felsőoktatási intézmény kutatja az űrszegmenshez köthető repülési dinamika ismérveit. A GNSS kifejezés egy világméretű helyzet-, sebesség- és időmeghatározó rendszerre vonatkozik, amely magában foglal egy vagy több műholdas konstellációt, vevőt és a rendszer integritásának ellenőrzését, szükség szerint kiegészítve a tényleges működési fázisban szükséges navigációs teljesítmény támogatásával.

\subsection{0. Űrélettani tudományágak ${ }^{49}$}

Nemzetközileg is elismert munka van jelen az űrdozimetria és az űrélettan területekein (biológiai, orvosi és élettani kutatás). A Nemzetközi Ûrállomáson magyar mérőműszerek biztosítják az ûrhajósokat érő kozmikus sugárzás detektálását.

\footnotetext{
${ }^{44}$ múholdas radar-interferometria fejlesztés, illetve tektonikus eredetű felszíndeformációk és más földfelszíni tömegátrendeződési folyamatok megfigyelése

${ }^{45}$ extrém alacsony frekvencia

${ }^{46}$ a magas légkör fizikai és kémiai folyamataival foglalkozó tudomány

${ }^{47}$ technológia, kutatás: BHE Bonn Hungary Kft., Budapesti Műszaki Egyetem - Szélessávú Hírközlési és Villamosságtan Tanszék, C3S Elektronikai Fejlesztő Kft., Wigner Fizikai Kutatóközpont Részecske és Magfizikai Intézet)

${ }^{48}$ technológia, kutatás: Budapesti Műszaki Egyetem, Lechner Tudásközpont Területi, Építészeti és Informatikai Nonprofit Kft.

${ }^{49}$ kutatás: Debreceni Egyetem - Ûrkutatási Program, TTK Kognitív Idegtudományi és Pszichológiai Intézet
} 
Hazai felsőoktatási intézmény munkacsoportokat hozott létre az űrutazások sugárfizikai, élettani, táplálkozási, orvosi és diagnosztikai ismérvek kutatása céljából. Céljuk az űrutazások gyakorlati megvalósíthatóságának, feltételeinek vizsgálata, az űrutazásban érintett asztronauták fizikai és mentális egészségének megőrzését biztosító utazási feltételeinek megteremtése.

Hazai pszichológiai intézet foglalkozik környezeti adaptáció kutatással és izolált kiscsoportok pszicho dinamikai folyamatainak vizsgálatával, földi űranalóg szimulációs tesztek feldolgozásával (az űrutazással járó stresszorok hatását vizsgálják a kognitív teljesítményre).

\subsection{Optika, optoelektronika ${ }^{50}$}

Hazai környezetben, földi távcsöves képalkotásra, fotometriára és spektroszkópiára alkalmas obszervatórium áll rendelkezésre, automatizált távcsövekkel.

Hazai nonprofit cég rendelkezik polarizációs, fluoreszcens és interferencia mikroszkóp megfigyelő rendszer fejlesztési és optimalizálási képességgel meteoritvizsgálatokhoz. Ugyan ez a cég bolygómegfigyelő kamerarendszer összeállítási képességgel is rendelkezik az UV, IR és CH4 tartományokban. Az űrszondás felvételeket 3D projektorrendszeren történő megjelenítéssel, animációk vetítésével is tudja biztosítani. A cég interaktív lézer, spektroszkópiai és fluoreszcens kísérleti eszközök fejlesztésében is jártas.

\subsection{2. Üridőjárás ${ }^{51}$}

Hazai felsőoktatási intézményben űridőjárási kutatások eredményei érhetőek el. A kutatások ULF-VLF sávban működő műszerek segítségével történnek, amelyeket magyar űripari céggel közösen fejlesztettek ki. Ezek az eszközök több műholdon, valamint a Nemzetközi Ûrállomáson telepítésre kerültek. Detektorok és elemző hálózatok segítségével képességnek tekinthető a plazmaszféra folyamatos monitorozása.

Hazai cégek vonatkozásában űridőjárás-jelentő rendszerfejlesztés projekttel is találkozhatunk. A perspektíva szerint az űridőjárási célra fejlesztett rendszerek az ESA, illetve hazánk műholdas és űridőjárás előre jelző rendszereinek szolgáltatnak majd adatokat, elősegítve az űrbéli és földi infrastruktúrák (pl. elektromos hálózatok, gázvezetékek) védelmét.

Az Országos Meteorológiai Szolgálatnak tapasztalata van a geostacionárius ${ }^{52}$, kvázipoláris pályájú és más meteorológiai műholdak adatainak alkalmazásában, feldolgozásában. A különböző sugárzási

\footnotetext{
${ }^{50}$ technológia, kutatás: Bay Zoltán Alkalmazott Kutatási Közhasznú Nonprofit Kft., Budapesti Műszaki Egyetem, Budapesti Múszaki Egyetem - Szélessávú Hírközlési és Villamosságtan Tanszék, Wigner Fizikai Kutatóközpont Szilárdtest-Fizikai és Optikai Intézet

${ }^{51}$ technológia, kutatás: CSFK Geodéziai és Geofizikai Intézet, Eötvös Lóránd Tudományegyetem Geofizikai és Ûrtudományi Tanszék - Ûrkutató Csoport, Energiatudományi Kutatóközpont, Országos Meteorológiai Szolgálat, Remred Technológia Fejlesztő Kft., Magyar Repülő és Ûrtechnológiai Platform ${ }^{52}$ geostacionárius műhold: a Földdel pontosan megegyező sebességgel mozgó, tehát a Földhöz képest mindig egy adott ponton és (igény szerint) egy adott irányba sugárzó műhold - alkalmazásával biztosítható a legtöbb földi
} 
tartományokban készült mérésekből, az adatokból elóállított képeknek, légköri és felszíni meteorológiai adatoknak jelentősége van a néhány órás előrejelzések előállításában, a repülési meteorológiában és a veszélyjelzésben. Emellett időjárás előre jelző rendszerekben, éghajlati és agrometeorológiai vizsgálatokban is felhasználják a múholdas adatokat.

Az üridőjárás és a kozmikus sugárzás kutatására alkalmas technológiák, módszerek kifejlesztése és alkalmazásba vétele - hazai, valamint nemzetközi ipari felhasználók részére - szintén egy hazai cég fő profilja. A cég képes olyam elemzés végrehajtására, amelyet az űridőjárás hatásai gyakorolnak az élő szervezetekre, elektronikai rendszerekre, energetikai hálózatokra.

\subsection{3. Ürfizika ${ }^{53}$}

Hazai oktatási intézményünk egyik fő kutatási iránya az ürfizika, ezen belül az elektromágneses hullámterjedés vizsgálata a mágnesezett plazmákban. Vizsgálódásuk kiterjed az űridőjárás, a plazmaszféra és a Van-Allen sugárzási övek kutatására nagyon alacsony frekvenciás (VLF) hullámok segítségével.

\subsection{Atommagkutatás ${ }^{54}$}

Neves hazai intézmény foglalkozik atommagkutatással és kapcsolódó szolgáltatásokkal, amelyek támogatják az űrkutatási tevékenységeket. Az atom-, molekula-, mag- és részecskefizika kutatások korszerű laboratóriumi környezetben adottak. Az intézmény ionnyaláb-analitikai, és a felületfizikai kutatási lehetőséget is biztosít. Részecskegyorsító Központban lehetőség nyílik a kutatási célú iongyorsítók használatba vételére. Sugárkárosodási vizsgálatok, anyagtudományi vizsgálatok, műszerek és módszerek fejlesztése, krio- és vákuumtechnikai szolgáltatások érhetőek el. Az intézmény rendelkezik nanokémiai laboratóriummal is.

\subsection{Nap és Naprendszer kutatása ${ }^{55}$}

Hazai csillagászati intézet foglalkozik a naprendszer kutatással. Tevékenysége a Földet megközelítő kisbolygók felfedezésére, követésére és tanulmányozására is irányul. Az intézet foglalkozik planetológiával, a csillag- és bolygókeletkezéssel, az exobolygókkal, a változócsillagokkal, a nukleáris asztrofizikával, a nap- és csillagaktivitással, a Tejút-rendszer szerkezetével, az extragalaktikus

szolgáltatás, és ezek mellett olyan képességek, melyekre az információs technológiai csatornák közül egyedül műhold(ak) alkalmazásával érhetőek el.

${ }^{53}$ kutatás: Eötvös Lóránd Tudományegyetem Geofizikai és Ûrtudományi Tanszék - Ûrkutató Csoport, Wigner Fizikai Kutatóközpont Részecske és Magfizikai Intézet

${ }^{54}$ kutatás: Atommagkutató Intézet, Isotoptech Zrt., Wigner Fizikai Kutatóközpont Részecske és Magfizikai Intézet

55 kutatás: Magyar Bányászati és Földtani Szolgálat Geofizikai Alapkutatási Osztály, Csillagászati és Földtudományi Kutatóközpont Geodéziai és Geofizikai Intézet, Csillagászati és Földtudományi Kutatóközpont Földtani és Geokémiai Intézet, Csillagászati és Földtudományi Kutatóközpont Konkoly Thege Miklós Csillagászati Intézet, Energiatudományi Kutatóközpont, Eötvös Lóránt Tudományegyetem, SGF Technológia Fejlesztő Kft., Wigner Fizikai Kutatóközpont Részecske és Magfizikai Intézet, Atommagkutató Intézet) 
tranziensekkel, az infravörös- és rádiócsillagászattal, űrfotometriával és a csillagászat történetével kapcsolatos kutatásokkal is.

\subsection{Anyagkezelési technológiák ${ }^{56}$}

A hazai környezetben, anyagkezeléssel foglalkozó szervezetek nagy számban fellelhetőek. Néhány példán keresztül ízelítőt lehet adni erről a képességről.

Hazai cég képes az űrmissziók alumínium alkatrészeinek környezetkímélő felületkezelése. Felületi rétegmérő eszközöket tudnak biztosítani. Képes - az ESA és az európai űrhardver gyártók előírásai szerint - műholdpálya függő rétegminősítő kvalifikációs eljárások lefolytatására. A műholdalkatrészek környezetbarát kromátozása és festése szintén megemlítendő.

Roncsolásos és roncsolás mentes anyagszerkezeti vizsgálatokat hazai kutatóintézet képes végrehajtani. Egy hazai nonprofit szervezet innovatív anyagok és technológiák, valamint anyagvizsgálati módszerek fejlesztésével képes csatlakozni űrkutatási projektekbe. A szervezet a szerkezeti és funkcionális anyagok, valamint a bevonatok kutatását és fejlesztését tűzte ki célul, fémes és nemfémes anyagok előállítási módszereinek és tulajdonságainak kutatása érdekében. A szervezet tapasztalatokkal rendelkezik a különböző anyagokból előállított felületi bevonat fejlesztésben, illetve a tapasztalat kiterjed ezen anyagtípusokból készült konkrét termékek, alkatrészek gyártásban történő alkalmazhatósági vizsgálataira is.

\section{Magyar űrképesség megtervezése}

Egy magyar műholdas képességgel szemben támasztott követelményeknek minimum feltétele, hogy fednie kell a Stratégiában meghatározott gazdasági, tudományos és nemzeti szuverenitási célokat.

Ebben a fejezetben bemutatásra kerül egy müholdas képesség kialakításának egy lehetséges módja a rendszer szolgáltatás portfóliójának meghatározásától kezdve annak üzembe helyezéséig, szem előtt tartva, hogy jelen publikáció íróinak nem célja egy különálló nemzeti űrstratégia megalkotása, csupán a legfőbb szempontok megfogalmazására törekszünk.

\subsection{A műholdas képesség koncepciójának kialakítása}

Első és egyben legfontosabb lépésként végre kell hajtani a szolgáltatási és funkcionális igények felmérését a kormányzati, a tudományos, a kutatási és kereskedelmi felhasználók által megfogalmazott igények alapján. Ezek az igények fogják meghatározni a műholdas képesség alapjait biztosító rendszer kialakítását mind az űr, mind a földi szegmens tekintetében.

\footnotetext{
56 kutatás: Admatis Kft., Atommagkutató Intézet, Bay Zoltán Alkalmazott Kutatási Közhasznú Nonprofit Kft., Csillagászati és Földtudományi Kutatóközpont Földtani és Geokémiai Intézet, Debreceni Egyetem - Ûrkutatási Program, Energiatudományi Kutatóközpont, Innobay Hungary Kft., Matmod Kft., Szegedi Tudományegyetem Nemlineáris Dinamika és Kinetika Csoport, Wigner Fizikai Kutatóközpont Szilárdtest-Fizikai és Optikai Intézet
} 
A felhasználói igények vizsgálatát és mérlegelését követően szükséges egy stratégiai szintű döntés meghozatala, ami a műszaki és gazdasági tervezés alapjait biztosítja. Ennek a stratégiai szintű döntésnek már tartalmaznia kell a pályára állítani kívánt múholdak mennyiségét, a múholdak pályamagasságát és a tervezett élettartamukat. Ezeken túlmenően meg kell határozni a biztosítandó szolgáltatások körét, mint például szuverén nemzeti adatkapcsolat, tudományos és kutatási célú adatszolgáltatás, média stream, polgári és nemzeti célú nyílt és titkosított infokommunikációs kapcsolat, kutatási és távérzékelési képességek lehetőségei (mérőszenzorok, érzékelők, kamerák stb.).

A tisztázott szolgáltatási portfólió alapján előzetes költségbecslést kell készíteni a tervezett műholdas rendszer gyártására és üzembeállítására vonatkozóan. Külön források tervezése szükséges a műholdas eszközpark üzembeállítását követően annak üzemeltetésére, üzemben tartására, figyelembe véve a műszaki területre jellemző gyors ütemű fejlődést és fejlesztést, amely kihatással van a használni kívánt rendszerelemekre. Forrásokat kell tervezni továbbá az üzemeltetés és a magas rendelkezésre állás szempontjából elengedhetetlenül fontos rendszer- és egység szintű tartalékképzésre és szoftverkövetésre. Fel kell mérni a felhasználói igények alapján és tervezni kell vele, hogy mekkora bevétel várható a nyílt piaci szegmenset célzó szolgáltatásokból. Már a projektnek ebben a szakaszában döntést kell hozni a biztosítandó adatszolgáltatások kapcsán az adatforgalmi típusokról (forgalom alapú vagy általány díjas). Célszerű egy financiálisan önfenntartó rendszer kialakítása, ahol a bevétel és a kiadás megközelítőleg egyensúlyban van.

A fenti bekezdésekben megfogalmazott kritériumok alapján egy átfogó megvalósíthatósági tanulmánytervet kell készíteni, ami tartalmazza az alapvető műszaki megvalósíthatósági tervváltozatokat és végig kíséri a tervezéstől a gyártáson keresztül a műholdak élettartamának végéig várható kiadásokat és bevételeket is.

\subsection{A projekt tervezése, szervezése}

A projekt sikeres lebonyolítása érdekében, figyelembe véve a feladat összetettségét és szerteágazóságát, munkacsoportok létrehozása szükséges olyan módon, hogy legyen egy projektvezetési munkacsoport és több almunkacsoport. A projektvezetési munkacsoport fő feladata a projekt teljes időtartama alatt az almunkacsoportok koordinálása és vezetése, a stratégiai szintű döntések meghozatala és a feladat egészére hatással lévő változások követése, nem utolsósorban a munkafolyamatok ellenőrzése.

Az almunkacsoportok kialakítása során törekedni kell arra, hogy minden olyan jelentős múszaki részterület lefedésre kerüljön, amely jól elkülöníthető funkcionális területet képez a rendszer elemeként (pl. műhold létfenntartás, kommunikációs részegység, szoftverfejlesztés, kutatási és tudományos részelemek stb.). A műszaki almunkacsoportokon túlmenően minden olyan önálló szakterület lefedésére almunkacsoportot kell létrehozni, amik szerves részét képzik a projekt sikeres lebonyolításának (pl. személyügyi, jogi, oktatási és kommunikációs feladatokhoz). Az almunkacsoportok felelősek a szakterületükre vonatkozó részfeladatok koordinálására és a más rendszerelemeket nem érintő változások követésére, továbbá beszámolási kötelezettséggel tartoznak a projektvezetési munkacsoport részére.

Javaslattétel munkacsoportok megalakítására: 
- Projekt vezetés - tervezés, koordináció, feladatok beazonosítása, magyar űripari vállalkozások képességeinek felmérése;

- Szolgáltatás alprojekt - szolgáltatás portfólió kialakítása;

- Technológiai alprojekt - szükséges technológia beazonosítása (meglévő rendszerek, magyar gyártástechnológiai képességek);

- Műhold alprojekt - technikai/műszaki megvalósítás (GEO műhold, LEO műholdak, földi követő és letöltő állomások, kereskedelmi célú és egyéb szolgáltatások földi kiszolgáló rendszerei);

- UÚrjogi alprojekt - jogi kérdések, engedélyeztetés, adminisztráció;

- Kormányzati alprojekt - kormányzati érdekeltségű felhasználás koordinálása;

- Humán-erőforrás alprojekt - személyügyi kérdések;

- Minősített rendszerek alprojekt - titkosított csatornák kivitelezése, minősített adminisztráció;

- Üzemeltetés alprojekt - a rendszer üzemeltetéséhez szükséges feltételek kidolgozása;

- Oktatás alprojekt - az üripart népszerűsítő nemzeti szintű oktatási program kidolgozása;

- Kommunikáció alprojekt - Magyar Ûrprogram népszerüsítése, kapcsolattartás a hazai és nemzetközi szereplőkkel.

A következő, kiemelten kezelendő lépés egy részletes ütemterv kidolgozása, ami a műholdas képesség tervezési fázisának elejétől a múholdas képesség elérésig terjed, amely már a teljes rendszer üzembe állítását jelenti. Az ütemterv tartalmazza továbbá a főbb szervezési és tervezési határidőket, valamint a rendszerelemek, majd a teljes rendszer tervezési, gyártási és ellenőrzési időperiódusait, figyelembe véve és kalkulálva az esetlegesen bekövetkező időbeli csúszásokkal.

A tervezési-szervezési fázis legfontosabb feladata a pályára állítani kívánt műhold vagy műhold flotta műszerezettségének pontos meghatározása, mely képes a szolgáltatás portfólióban meghatározott igények kiszolgálására. Fontos kritérium a hosszútávra történő tervezés, mivel egy-egy műhold 10-15 évig is szolgálatban állhat, így a jelenkor csúcstechnológiás berendezései - tekintve, hogy a felbocsátást követően azok hardver szintű fejlesztésére nincs lehetőség - a jövőben „elavulttá” válnak. Az eszközpark meghatározása egy nagy szakértelmet kívánó, bonyolult és hosszadalmas folyamat, mivel a fedélzeti műszerek mind egymásra, mind pedig a „mérendőre” hatást gyakorolnak, továbbá a műholdas rendszer minden más egységének tervezése szükségszerűen ehhez igazodik. Ebből kifolyólag a műszerezettség meghatározását követően azon módosítani már nem lehetséges („freeze” állapot).

Az elfogadott átfogó megvalósíthatósági tanulmányterv és az ütemterv alapján részletes műszaki kiviteli tervet kell kidolgozni, amely tartalmaz minden olyan technikai, technológiai és műszaki paramétert, ami alapján a kivitelezés megkezdhető és végrehajtható.

Készíteni szükséges a projektre vonatkozóan egy teljes körű kockázatelemzést, amely magába foglalja a projekt sikeres kimenetelét befolyásoló vagy akadályozó összes tényezőt.

A kiviteli tervek alapján ellenőrzés és műszaki felülvizsgálat céljából végre kell hajtani egy (műhold és földi rendszerek együttesen) rendszer- és egységszintű működőképesség vizsgálatot szimulált környezetben. 
Az almunkacsoportok egyetértő támogatása és javaslatai alapján a kiviteli terveket a projektvezetési munkacsoport véglegesíti és jóváhagyja.

A véglegesített tervek alapján a kivitelezést végző „Upstream” és „Downstream” cégek kiválasztása során törekedni kell a nemzeti érdekeltségű vállalkozások megbízására és hazai fejlesztésű eszközök felhasználására.

A véglegesített tervek alapján elvégezhető az anyagi források felhasználásának elosztástervezése, melyet a projekt végrehajtási szakasza követ.

\subsection{A képesség kialakításának végrehajtása, realizálás}

A felbocsátást végző vállalatok szigorú időrend szerint végzik tevékenységüket, mely a nagyfokú leterheltségükből fakad, így egy műhold feljuttatásának időpontját már hosszú időre előre szükséges tervesíteni.

Fentiekre tekintettel a végrehajtás fázisának kritikus része az ütemterv szerinti kivitelezés, valamint az abban foglaltaktól történő bármely (legfőképpen időbeli) eltérés figyelemmel kísérése és koordinálása.

Az ütemterv be nem tartása azt eredményezheti, hogy a pályára állítani kívánt műhold a meghatározott időre nem kerül felbocsátásra kész állapotba, mely a műholdas képesség kialakításának lehetőségét nagymértékben visszaveti.

Kifejezetten fontos tehát a kivitelezésben nagy tapasztalattal és szaktudással rendelkező nemzeti illetőségű vállalkozások bevonása, mely már önmagában megnövelheti a müholdas képesség kialakításának sikerességét.

\subsection{A rendszer tesztelése, pályára állítás}

A múholdas rendszer (műhold és földi rendszerek) elkészültét követően a kivitelezést végző vállalkozások részéről szükséges egy részletes rendszerleíró tervdokumentáció elkészítése és az üzemeltetést későbbiekben végzők részére történő átadása, mely a műholdas rendszerben esetlegesen fellépő hibák, anomáliák, rendellenes működések hatékony behatárolását és elhárítását segítik elő.

A rendszer elkészültét követően, de még a felbocsátást megelőzően szükséges a kivitelezők és az üzemeltetést végzők bevonásával történő mérések és tesztek sorozatának végrehajtása mind a rendszer egészére, mind pedig a rendszer részegységeire vonatkozóan.

A rendszer ilyen irányú vizsgálata során fontos momentum a mért értékek és a rendszerleíró tervdokumentációban szereplő adatok összevetése, mely szintén a későbbiekben előforduló hibabehatárolást és hibaelhárítást támogatja.

A mérést és tesztelést követően szükséges a műholdas rendszer tesztüzembe helyezése, mely kiterjed a tartalék rendszerek múködőképességének vizsgálatára és tesztelésére is (szimulált meghibásodások stb.). A tesztüzem természetesen nem képes teljeskörűen leképezni a rendszer valós környezetben történő viselkedését, mivel az ûrbéli környezet földi körülmények közötti szimulációja csak részben lehetséges. 
A tesztsorozatok végrehajtását követően utolsó lépésként megkezdődhet a műholdas eszköz(ök) szállítmányozása a kilövés helyszínére, végül az(ok) felbocsátása és pályára állítása.

\subsection{A projekt befejezése, összegzés}

A műholdas képesség kialakításának utolsó mozzanata a képesség kialakítását követően, a projekt, valamint a szerződések lezárása, továbbá a projekt során szerzett tapasztalatok feldolgozása és a tudásbázis felépítése. A fentiekben felvázolt modell alapvetően tehát négy alappilléren nyugszik:

- Szolgáltatás portfólió pontos meghatározása;

- Műhold műszerezettségének meghatározása a szolgáltatás portfólió ismeretében;

- Az ütemterv szigorú - főként időbeli - követése;

- Tesztelés és dokumentálás az üzemeltetés során esetlegesen fellépő meghibásodások behatárolásához és elhárításához.

E négy pillér folyamatos szem előtt tartása kritikus fontosságú, melynek hiányában a múholdas képesség kialakítása hiányossá válhat vagy ellehetetlenülhet.

\section{Összegzés}

Magyarország űrképességének elérésének kritikus feltétele a 2024. évre történően egy geostacionárius műhold, ezt követően pedig több LEO műhold ${ }^{57}$ pályára állításával egy, a Stratégiában foglalt célok eléréséhez és az abban foglalt feladatok teljesítéséhez szükséges képességek szem előtt tartásával létrehozott műholdrendszer megalkotása. Jelen publikációban törekedtünk ezen cél stratégiai kulcsfontosságának- és az eléréséhez végrehajtandó feladatrendszer összetettségének érzékeltetésére. A „Magyar űripari képességek” fejezetben ismertetett jelenlegi kompetenciák nem csupán a fentiekben megfogalmazott, most még rendkívül ambiciózusnak tetsző cél hazai erőfeszítésekkel és magasan koordinált munkával történő elérését teszik lehetővé, de utat nyitnak egy saját űripari ökoszisztéma megteremtése felé is.

Napjainkban már nem beszélhetünk nyugodt szívvel nemzetbiztonságról, önálló nemzeti műholdas képesség nélkül. A tény, hogy a biztonságpolitika már a közeljövőben - ha már nem a jelenben is áttevődik a világürbe, olyan fajsúllyal bír, amelynek figyelmen kívül hagyása hosszú távon nagyon komoly politikai és gazdasági leszakadást jelenthet egy-egy nemzet számára. A szuverenitás és a nemzeti érdekérvényesítés erősítése mellett egy geostacionárius műhold alkalmazásában jelentős anyagi haszon is rejlik. A kettő egyidejűleg történő alkalmazásával Magyarország komoly lépéseket tehet előre az általa kijelölt fejlődésorientált úton.

A jövőben akár egy nemzet, akár egy nemzetközi szervezet biztonsági aspektusainak vizsgálatakor elengedhetetlen tényezővé válik az űrbiztonság, mint különálló biztonsági faktor szem előtt tartása és az azzal szemben támasztott követelményeknek való megfelelés. Az űrbiztonság többek között az

\footnotetext{
${ }^{57} \mathrm{Az}$ alacsony Föld körüli pályán (Low Earth Orbit, rövidítve LEO) keringő műhold, amely a Föld felszínétől legfeljebb 2000 km távolságra van.
} 
űridőjárás mérését és előrejelzését, földközeli objektumok (aszteroidák) és potenciálisan veszélyes űrszemét megfigyelését foglalja magába, amely jelenségek közvetlen és súlyos hatással lehetnek egy nemzet múködésére is, mind gazdasági, mind biztonsági szempontból. Szuverén műholdrendszer megléte esetén korunk technológiai színvonalának megfelelő legkorszerűbb eszközrendszerrel állna rendelkezésre egy nemzet jólétét megőrizni képes technológia.

\section{Felhasznált Irodalom}

[1] C3S: C3S Elektronikai Fejlesztő Kft. weboldal; (https://www.c3s.hu/); Letöltve: 2020. 09. 02

[2] HUNSPACE: Magyar Üripari Klaszter weboldal; (http://hunspace.org); Letöltve: 2020. 09. 02

[3] NATO'S APPROACH TO SPACE: (https://www.nato.int/cps/en/natohq/topics_175419.htm) Letöltve: 2020.09. 02

[4] NBS (2020): A Kormány 1163/2020. (IV. 21.) Korm. határozata Magyarország Nemzeti Biztonsági Stratégiájáról

[5] (https://magyarkozlony.hu/dokumentumok/6c9e9f4be48fd1bc620655a7f249f81681f8ba67/let oltes); Letöltve: 2020. 08. 19

[6] SPACEPOWER, (2020) : Space Capstone Publication; Doctrine for Space Forces (https://www.space.com/space-force-spacepower-doctrine-capstone.html);

Letöltve: 2020. 08. 19

[7] SPACE STRATEGY FOR EUROPE: Communication from the Commission to the European Parliament, the Council, the European Economic and Social Committee and the Committee of the Regions; (https://ec.europa.eu/docsroom/documents/19442); Letöltve: 2020. 09.01

ÜRKÖRKÉP, (2019): Hazai Ürkörkép; (https://www.mant.hu/kiadvanyok/Urkorkep2019.pdf); Letöltve: 2020.09. 02 